\title{
CARBON LEAKAGE IN THE EU IN THE LIGHT OF THE PARIS CLIMATE AGREEMENT
}

\author{
Melita Carević
}

\begin{abstract}
Summary: Despite the recent adoption of the Paris climate agreement, countries taking climate change action are still faced with a potential risk of carbon leakage due to the absence of a uniform carbon price at the global level. This paper analyses the European Union's current and proposed carbon leakage legislation in order to identify its strengths and weaknesses. It emphasises that the environmental and economic integrity of the European Union's measures is of crucial importance due to the fact that the European Union's leadership in global climate legislation is highly dependent on it and also since the European Union's legislation has already served and is likely to continue serving as a model for similar cap and trade systems worldwide. The paper concludes that the current regulation of carbon leakage in the European Union leads to the overprotection of sectors which are considered to be exposed to a significant risk of carbon leakage and that further revisions of the system are necessary.
\end{abstract}

\section{Introduction}

At the time of finalising this paper, the 21 st Conference of the Parties to the United Nations Framework Convention on Climate Change in Paris (hereinafter: COP 21) has resulted in a historic breakthrough in climate change negotiations - an agreement applicable to all parties, requiring them to take action with the aim of 'holding the increase in the global average temperature to well below $2{ }^{\circ} \mathrm{C}$ above pre-industrial levels and [...] pursu[ing] efforts to limit the temperature increase to $1.5^{\circ} \mathrm{C}$ above preindustrial levels'. ${ }^{1}$ However, since the implementation of the Paris Agreement is scheduled to start from 2020, countries undertaking greenhouse gas emission reduction measures prior to 2020 will still be faced with a potential risk of carbon leakage. That risk is likely to remain present even after 2020, due to the fact that no uniform carbon price will be set

\footnotetext{
Melita Carević, DSc, research fellow at the Jean Monnet Chair of European Public Law at the University of Zagreb Law School. Research for this paper was conducted under a University of Zagreb Law School research project. Parts of the text of this paper are included in my doctoral thesis entitled 'European Union Climate Change Regulation and Its Impact on Global Standard-Setting'.

1 Conference of the Parties to the United Nations Framework Convention on Climate Change, Adoption of the Paris Agreement, 12 December 2015, Article 2 <http://unfccc.int/ resource/docs/2015/cop21/eng/109r01.pdf > accessed 12 December 2015.
} 
at the global level. The environmental and economic integrity of climate change mitigation measures taken by early actors, such as the European Union, therefore depends on the ability of those measures to cope with the issue of carbon leakage. Given the fact that the European Union is one of the few members of the international community that has a set greenhouse gas emission reduction target under the second commitment period of the Kyoto Protocol to the United Nations Framework Convention on Climate Change (hereinafter: Kyoto Protocol), the European Union will continue facing a potential risk of carbon leakage at least until the end of 2020 .

The aim of the present paper is to analyse carbon leakage mitigation measures which are currently in force in the European Union, as well as the European Commission's recent proposal for the revision of those measures, and to examine how those measures fit into the European Union's long-term goal of being a global leader in the fight against climate change. The underlying assumption of the research is that, in order to be perceived as legitimate in the eyes of the parties to the United Nations Framework Convention on Climate Change (hereinafter: UNFCCC), the European Union's carbon leakage mitigation measures must genuinely contribute to the economic and environmental integrity of the Union's climate change policy and that they must not lead to the overprotection of certain carbon intensive sectors. The latter result would be liable to seriously endanger the Union's credibility in international climate change politics which would not be beneficial to the Union's ability to provide leadership during the UNFCCC negotiations. Despite the fact that a long awaited crucial step has been taken in Paris by the adoption of a new climate change agreement, the challenging task of its implementation still lies ahead and will require strong leadership in order to ensure the effectiveness of the agreement. It is therefore important that the European Union, together with other major economies and greenhouse gas emitters, such as the USA, continues to push for ambitious climate change action and thereby enjoys the confidence of the international community. Last, as the European Union's climate change legislation, including provisions on carbon leakage, have already served and are likely to serve as a model for climate change regulation worldwide, its efficiency plays an important role in global climate change mitigation.

This paper shall first examine how the issue of carbon leakage is addressed in the European Union's Emission Trading Scheme (hereinafter: EU ETS), the Union's main instrument for reducing greenhouse gas emissions from stationary sources. The analysis will focus on the current legislative solutions contained in Directive 2003/87 / EC of the European Parliament and of the Council establishing a scheme for greenhouse gas emission allowance trading within the Community and amending Coun- 
cil Directive 96/61/EC (hereinafter: EU ETS Directive). ${ }^{2}$ Attention shall also be paid to the European Commission's Proposal for a Directive of the European Parliament and of the Council amending Directive 2003/87/ EC to enhance cost-effective emission reductions and low-carbon investments (hereinafter: Commission's EU ETS amendment proposal from $2015)^{3}$ which was issued in July 2015. The research will aim to identify the main strengths and weaknesses of the current legislative solutions. The conclusions of the analysis will be used to examine the legitimacy of the Union's carbon leakage mitigation.

\section{Defining carbon leakage}

For the purposes of this paper, carbon leakage can be defined as an increase in greenhouse gas emissions which takes place as a result of climate change regulation outside the area subject to such regulation. The notion itself was coined by Felder and Rutherford in $1993^{4}$ and has been defined by several authors in a more or less similar fashion. The Fourth Report of the Intergovernmental Panel on Climate Change from 2007 defines carbon leakage as: 'the increase in $\mathrm{CO}_{2}$ emissions outside the countries taking domestic mitigation action divided by the reduction in the emissions of these countries'. ${ }^{5}$ An OECD/IEA definition, coined by Reinaud, follows the same logic:

Carbon leakage can be defined as the ratio of emissions increase from a specific sector outside the country (as a result of a policy affecting that sector in the country) over the emission reductions in the sector (again, as a result of the environmental policy). When handling this issue, the aim is to address environmental effectiveness, not industrial policy. ${ }^{6}$

\footnotetext{
2 Directive 2003/87/EC of the European Parliament and of the Council establishing a scheme for greenhouse gas emission allowance trading within the Community and amending Council Directive 96/61/EC (consolidated text as amended by Directive 2004/101/ EC, Directive 2008/101/EC, Regulation No 219/2009, Directive 2009/29/EC, Decision No 1359/2013/EU and the Treaty of Accession of Croatia, Regulation 421/2014).

3 Commission, 'Proposal for a Directive of the European Parliament and of the Council amending Directive 2003/87/EC to enhance cost-effective emission reductions and lowcarbon investments' COM (2015) 337 final, 2015/148 (COD).

4 Guy Meunier and Jean-Pierre Ponnsard, 'Capacity Decisions with Demand Fluctuations and Carbon Leakage' (2014) 36 Resource and Energy Economics 436, 437, citing S Felder and $\mathrm{T}$ Rutherford, 'Unilateral $\mathrm{CO}_{2}$ Reductions and Carbon Leakage: The Consequences of International Trade in Oil and Basic Materials' (1993) 25(2) Journal of Environmental Economics and Management 162.

5 IPCC, Climate Change 2007, Mitigation of Climate Change, $665<$ http://www.ipcc.ch/ pdf/assessment-report/ar4/wg3/ar4_wg3_full_report.pdf > accessed 2 November 2015.

6 Julia Reinaud, 'Issues Behind Competitiveness and Carbon Leakage: Focus on Heavy Industry' IEA Information paper, OECD/IEA (2008) $3<$ http://www.ictsd.org/downloads/2008/11/iea-paper-on-issues-behind-competitiveness_and_carbon_leakage.pdf
} 
Similarly, carbon leakage was also defined as the additional $\mathrm{CO}_{2}$ emissions of non-mitigating participants (ie subjected to a weak reference policy) compared to the $\mathrm{CO}_{2}$ abatement achieved by pioneering regions (ie pursuing additional policy ambition), ${ }^{7}$ and as a 'partial offset of domestically reduced GHG emissions in countries with less stringent environmental requirements and is hence a measure of reduced environmental effectiveness'. ${ }^{8}$ It has also been defined more simply as 'the increase in emissions outside a country that are directly attributable to the introduction of climate regulations introduced in that country'. ${ }^{9}$

A common element in all the aforementioned definitions is the fact that carbon leakage occurs as the result of asymmetrical climate change policies ${ }^{10}$ in different regulatory areas, such as states or regions. ${ }^{11}$ In other words, carbon leakage can be considered as an inevitable consequence of the lack of a global-wide carbon reduction policy regulated by an international agreement which is binding on the majority of the members of the international community, or at least on major emitters of greenhouse gasses. ${ }^{12}$ Carbon leakage, interconnected with the principle of 'common but differentiated responsibilities', therefore undoubtedly represents the most controversial issue of the contemporary global climate change governance. It raises high levels of concern related both to environmental and economic aspects.

From the environmental point of view, carbon leakage compromises the environmental integrity of the greenhouse gas reduction measures

accessed 2 November 2015.

7 Tabaré Arroyo-Currás and others, 'Carbon Leakage in a Fragmented Climate Regime: The Dynamic Response of Global Energy Markets' (2015) 90 Technological Forecasting \& Social Change 192, 192. <http://dx.doi.org/10.1016/j.techfore.2013.10.002> accessed 2 November 2015.

8 Birgit Bednar-Friedl, Thomas Schinko and Karl W Steininger, The Relevance of Process Emissions for Carbon Leakage: A Comparison of Unilateral Climate Policy Options With and Without Border Carbon Adjustment' (2012) 34 Energy Economics 5168, 5168. Similarly in Meunier and Ponnsard (n 4) 436

9 Robyn Eckersley, 'The Politics of Carbon Leakage and the Fairness of Border Measures' (2010) 24(4) Ethics \& International Affairs 367, 370.

10 For the definition of asymmetrical climate change policies, see Andrei Marcu and others, 'Carbon Leakage: Options for the EU' CEPS Special Report of 11 March 2014, 2 <http:// www.ceps.eu/book/carbon-leakage-options-eu> accessed 2 November 2015.

11 Certain authors suggest that domestic increases of greenhouse gas emissions in nonregulated sectors, which take place due to the regulation of other sectors, should also be encompassed by the definition of carbon leakage. Elisa Lanzi and others 'Addressing Competitiveness and Carbon Leakage Impacts Arising from Multiple Carbon Markets: A Modelling Assessment' (2013) OECD Environment Working Papers No 58, OECD Publishing, 14 <http://www.oecd-ilibrary.org/docserver/download/5k40ggij7z8v.pdf?expires $=141011$ 0347\&id=id\&accname=guest\&checksum=AFD2AE5856A256044F5A71280C93B21D>accessed 2 November 2015.

12 Similarly in Arroyo-Currás and others (n 7) 192; Onno Kuik, and Marjan Hofkes, 'Border Adjustment for European Emissions Trading: Competitiveness and Carbon Leakage' (2010) 38(4) Energy Policy 1741, 1741. 
adopted by a certain state or region. Since climate change is a global problem, due to the fact that greenhouse gasses mix in the atmosphere and contribute to global warming regardless of the area from which they are emitted, only a global solution can deal with the problem efficiently. The reductions of greenhouse gases emitted by a state which regulates greenhouse gas emissions will not produce satisfactory results if, because of that regulation, greenhouse gas emissions shift to another state with less stringent or no similar regulation (so called 'carbon havens'), ${ }^{13}$ since the total level of emitted greenhouse gasses will remain the same, or potentially even increase. Therefore, from the environmental perspective, a measure which aims to reduce greenhouse gas emissions can only be effective if it does not at the same time induce carbon leakage which results in the increase of emissions elsewhere. In this regard, for the environmental integrity of the country's emission reduction targets, it is equally problematic if the increase of emissions takes place as a result of the reallocation of the production itself from the regulating country, or if it takes place in the form of higher volumes of imported products with a high carbon content, which have been produced without the internalisation of carbon cost. From the environmental perspective, the latter example of 'stowaway carbon'14 should therefore also be taken into account when assessing the level of emission reductions, for which Eckersley suggests the following formula: 'The final carbon consumption in any given country equals the amount of carbon produced domestically minus the embodied carbon in exports plus the embodied carbon in imports'. ${ }^{15}$ Such a method of calculating greenhouse gas emission attributable to a certain state therefore takes note of the increase of emissions outside that state which is directly attributable to its climate change regulation, as well as to the increase in emissions which is attributable to global trade patterns not necessarily related to climate regulation, since it is in practice difficult to distinguish the two. Otherwise, the achievement of emission reduction goals by the states taking reduction measures cannot be considered genuine and to be leading to the overall reduction of emissions at the global level. ${ }^{16}$

On the other hand, from the economic point of view, carbon leakage is observed through the spectrum of economic consequences it produces

\footnotetext{
13 Eckersley (n 9) 369; Neil Peretz, 'Carbon Leakage Under the European Union Emissions Trading Scheme: Is It a Major Policy Concern?' (2009) 23 Tulane Environmental Law Journal 57,83 . However, it should be noted that unlike other types of pollution havens, carbon havens do not represent an imminent threat to the area where they are concentrated, but, instead, due to the nature of carbon 'pollution', represent a global climate risk. This results in a freeriding incentive, since states that do not enact climate change mitigation measures do not necessarily suffer the gravest environmental consequences for their inaction.

14 Eckersley (n 9) 370.

15 ibid.

16 Similarly in Yassen Spassov, 'EU ETS: Upholding the Carbon Price without Incidence of Carbon Leakage' (2012) 24(2) Journal of Environmental Law 311, 316.
} 
on the territory of the state or region which implements greenhouse gas reduction measures. States or regions which regulate greenhouse gas emissions oblige greenhouse gas emitters to internalise the cost of those emissions, which would otherwise be considered an externality and not accounted for in their production costs. Consequently, since the cost of carbon is included in the production costs of economic subjects on the territory of a state with greenhouse gas emissions regulation, in undisturbed market conditions their products are less competitive than substitutable products coming from states with no greenhouse gas regulation. The economic and environmental aspects of carbon leakage can both nicely be seen in the definition formulated by Meltzer: 'Carbon leakage arises when a carbon price leads domestic businesses to relocate to countries not pricing carbon or to increased imports of goods from countries not pricing carbon, resulting in no net reduction of global $\mathrm{CO}_{2}$ emissions'. ${ }^{17}$ However, it must be noted that the environmental and economic aspects of carbon leakage do not necessarily go hand in hand with one another. From the economic aspect, it is important to prevent the shift of production from a state which regulates greenhouse gas emissions, while from the environmental point of view it is important to achieve a net reduction of greenhouse gas emissions, regardless of whether it leads to reallocation of production. ${ }^{18}$

\section{Current legislative solutions in the European Union}

The EU ETS Directive contains several provisions dealing with the issue of carbon leakage. ${ }^{19}$ It defines the sectors which are deemed to be at 'significant risk of carbon leakage' and foresees several types of measures for the mitigation of such risk. The provisions of the EU ETS Directive dealing with the issue of carbon leakage will now be analysed in detail, in order for their main strengths and weaknesses to be identified.

\subsection{Identifying sectors at 'significant risk of carbon leakage'}

The criteria for assessing carbon leakage risk and measures for the mitigation of that risk were first introduced into the EU ETS Directive by the 2009 amendments contained in Directive 2009/29/EC, ${ }^{20}$ which brought significant changes to the allocation of allowances enacted for the third period of the EU ETS, running from 2013 until 2020. The EU

\footnotetext{
17 Joshua Meltzer, 'Climate Change and Trade: The EU Aviation Directive and the WTO' (2012) 13(1) Journal of International Economic Law 111, 111.

18 Eckersley (n 9) 370.

19 The explanation of the notion of carbon leakage can be found in recital 24 of the Directive's amendment of 2009.

20 Directive 2009/29/EC of the European Parliament and of the Council of 23 April 2009 amending Directive 2003/87/EC so as to improve and extend the greenhouse gas emission allowance trading scheme of the Community [2009] OJ L140/63.
} 
ETS Directive from 2003 did not contain any mention of carbon leakage, which can be explained by the fact that emission allowances were all allocated for free during the test period of the EU ETS, ${ }^{21}$ running from 2005 until 2007, and that the during the second trading period, running from 2008 until 2012, the majority of the allowances were also allocated free of charge, and only an insignificant number of them auctioned. ${ }^{22}$ In other words, since greenhouse gas emissions did not represent a significant production cost during the first two trading periods and since a lower number of industry sectors were covered by the scheme, there was no need to account for carbon leakage in the EU ETS Directive. However, the 2009 amendments introduced auctioning on a much wider scale. According to an approximation made by the European Commission's DG Climate Action, 'over $40 \%$ of allowances were auctioned' in $2013,{ }^{23}$ which, even though free allocation remained the dominant method of allowance distribution, represented a significant step when compared to the previous commitment periods. Consequently, as the EU ETS became more stringent, the risk of carbon leakage increased and the provisions for its mitigation were included in the Directive. The level of auctioned allowances is scheduled to further decrease by $1.74 \%$ annually until 2020 , and by $2.2 \%$ annually from 2021 until 2030.

The EU ETS Directive envisages quantitative and qualitative criteria for assessing the carbon leakage risk.

Pursuant to Article 10(a), paragraphs 15 and 16 of the consolidated text of the Directive, the quantitative criteria for assessing the risk of carbon leakage are the following:

15. A sector or subsector shall be deemed to be exposed to a significant risk of carbon leakage if:

(a) the sum of direct and indirect additional costs induced by the implementation of this Directive would lead to a substantial increase of production costs, calculated as a proportion of the gross value added, of at least 5\%; and

(b) the intensity of trade with third countries, defined as the ratio between the total value of exports to third countries plus the value

\footnotetext{
21 Article 10 of the 2003 EU ETS Directive prescribed that at least 95\% of allowances are to be allocated for free during the first phase of the EU ETS.

22 European Commission, DG Climate Action, EU ETS 2005-2012, < http://ec.europa.eu/ clima/policies/ets/pre2013/index_en.htm> accessed 2 November 2015. Article 10 of the 2003 EU ETS Directive prescribed that at least 90\% of allowances are to be allocated for free during the second phase of the EU ETS. However, only some Member States decided to make use of the auctioning option. A Denny Ellerman, Frank J Convery, and Christian de Perthuis, Pricing Carbon: The European Union Emissions Trading Scheme (CUP 2010) 62.

23 DG Climate Action, Auctioning <http://ec.europa.eu/clima/policies/ets/cap/auctioning/index_en.htm> accessed 2 November 2015.
} 
of imports from third countries and the total market size for the Community (annual turnover plus total imports from third countries), is above $10 \%$.

16. Notwithstanding paragraph 15 , a sector or subsector is also deemed to be exposed to a significant risk of carbon leakage if:

(a) the sum of direct and indirect additional costs induced by the implementation of this Directive would lead to a particularly high increase of production costs, calculated as a proportion of the gross value added, of at least $30 \%$; or

(b) the intensity of trade with third countries, defined as the ratio between the total value of exports to third countries plus the value of imports from third countries and the total market size for the Community (annual turnover plus total imports from third countries), is above $30 \%$.

The EU ETS Directive therefore prescribes two separate sets of quantitative criteria for determining whether a specific sector is subject to a significant risk of carbon leakage. Paragraph 15 lays down two conditions that have to be fulfilled cumulatively, but which are therefore less stringent. The criteria which are deemed to expose a sector to risk of carbon leakage are direct costs of complying with the requirements of the EU ETS, that is, the carbon costs incurred during production, indirect costs that arise due to the increase in energy prices, the intensity of trade with third countries, and market share. On the other hand, paragraph 16 prescribes two alternative criteria with a higher threshold, which are applicable to sectors which either suffer a high direct or indirect cost due to the application of the EU ETS, or are significantly exposed to trade with third countries, which renders their market position vulnerable to foreign competition.

These quantitative criteria are furthermore supplemented by qualitative criteria which are prescribed by Article 10(a)17:

The list referred to in paragraph 13 may be supplemented after completion of a qualitative assessment, taking into account, where the relevant data are available, the following criteria:

(a) the extent to which it is possible for individual installations in the sector or subsector concerned to reduce emission levels or electricity consumption, including, as appropriate, the increase in production costs that the related investment may entail, for instance on the basis of the most efficient techniques;

(b) current and projected market characteristics, including when trade exposure or direct and indirect cost increase rates are close to one of the thresholds mentioned in paragraph 16; 
(c) profit margins as a potential indicator of long-run investment or relocation decisions.

The main purpose of the qualitative criteria is to ensure that the stringency of the quantitative criteria are addressed and to make sure that the sectors that do not satisfy the quantitative thresholds are not, due to their specificities, unjustifiably left out of the list, or that some sectors which have been put on the list are removed from it. However, the qualitative criteria have so far been used just for the inclusion of additional sectors to the list, and not for the assessment of whether some sectors have unjustifiably been put on the list. ${ }^{24}$ Due to time constrains, in 2009, for the purposes of composing the first carbon leakage list for the period 2013-2014, only the sectors which bordered with the quantitative thresholds and some specific sectors were examined on the basis of qualitative criteria, ${ }^{25}$ and five sectors were identified as exposed to significant risk of carbon leakage and added to the list. ${ }^{26}$ In 2014 , for the purposes of composing the second carbon leakage list for the period running from 2015 until 2019, six sectors were added to the list on the basis of qualitative criteria from Article 10(a) $17 .{ }^{27}$

The final factor which should be taken into account when determining the sectors which are exposed to significant risk of carbon leakage is whether the commitment of third countries, which represent an important share of global production in a given sector, to greenhouse gas emission reductions and the carbon efficiency of their installations are comparable to those of the Union. ${ }^{28}$ This factor is very important because comparable climate mitigation action of major trading partners minimises or even eliminates the need to protect a given sector from carbon leakage. However, it seems that the wording of Article 10(a)18 of the EU ETS Directive only requires that third countries are firmly committed to reducing their greenhouse gas emissions, and does not go so far as to require that they actually achieve those reductions in practice. This wording can perhaps

\footnotetext{
24 Susanne Dröge and Simone Cooper, 'Tackling Leakage in a World of Unequal Carbon Prices: A Study for the Greens/EFA Group' (May 2010) Climate Strategies 27.

25 Draft Commission Staff Working Document, Impact Assessment Accompanying the Document to the Commission Decision determining a list of sectors and subsectors which are deemed to be exposed to a significant risk of carbon leakage pursuant to Article 10a (13) of Directive 2003/87/EC, C(2009)10251 final, 18 <http://ec.europa.eu/clima/policies/ets/ cap/leakage/docs/sec_2009_1710_en.pdf > accessed 2 November 2015.

26 According to the data provided by an official of DG Climate Action. H Bergman, 'Sectors Deemed To Be Exposed to a Significant Risk Of Carbon Leakage: Outcome of the Assessment, WG 3 Meeting 18 September 2009' 9 <http://ec.europa.eu/clima/policies/ets/cap/ leakage/docs/wg3_16_sep_presentation_en.pdf $>$ accessed 2 November 2015.

27 Commission Decision of 27 October 2014 determining, pursuant to Directive 2003/87/ EC of the European Parliament and of the Council, a list of sectors and subsectors which are deemed to be exposed to a significant risk of carbon leakage, for the period 2015 to 2019 (2014/746/EU) 124.

28 Article 10 (a) 18 of the EU ETS Directive.
} 
be explained by the difficulty of measuring actual greenhouse gas emissions which are attributable to a certain policy instrument. However, in the current form it does not ensure the environmental effectiveness of the EU's greenhouse gas reduction measures, but only prevents economic leakage, since it presumably requires that a comparable carbon price is put on emissions in third countries.

While determining the list of sectors which are considered to be exposed to significant risk of carbon leakage in the 2015-2019 period, the Commission undertook the aforementioned analysis and concluded that no comparable action was being taken by third countries and therefore considered this criterion to be irrelevant for the determination of the list. ${ }^{29}$ However, the Commission will have a more demanding task of assessing climate change mitigation efforts of its trading partners when drafting the third carbon leakage list for the post 2019 period, as more and more countries are introducing different forms of greenhouse gas reduction measures. For example, in January 2015 South Korea introduced a cap and trade system modelled after the EU ETS. ${ }^{30}$ The production of steel, which South Korea exports into the EU among other countries, and which is considered to be exposed to significant risk of carbon leakage in the EU, is covered by the scheme. ${ }^{31}$ Furthermore, several regional pilot cap and trade systems have been put in place in one of the Union's main trading partners, China, and a national cap and trade system has been announced for 2017. ${ }^{32}$ The USA has also stepped up its greenhouse gas emission reductions by adopting the Carbon Pollution Standards for Existing Power Plants in August 2015, and by putting in place regional cap and trade systems. ${ }^{33}$ Depending on the success of third-country measures and their trade with the EU in the relevant sectors, it is not unlikely that the Commission will have to perform the above-mentioned analysis in the near future for the purposes of amending the current carbon leakage list. While assessing the comparability of third-country action, the

29 Commission Decision of 27 October 2014 determining, pursuant to Directive 2003/87/ EC of the European Parliament and of the Council, a list of sectors and subsectors which are deemed to be exposed to a significant risk of carbon leakage, for the period 2015 to 2019 (2014/746/EU), recital 3.

30 Reuters, 'South Korea Launches World's Second-Biggest Carbon Market'(12 January 2015) <http:/ / in.reuters.com/article/southkorea-carbontrading-idINKBNOKL05K20150112> accessed 2 December 2015.

31 International Carbon Action Partnership, Korea Emissions Trading Scheme, 2 <https:// icapcarbonaction.com/en/?option=com_etsmap\&task=export\&format=pdf\&layout=list\&sy stems\%5B\%5D=47> accessed 2 December 2015.

32 Julie Hirschfeld Davis and Coral Davenport, 'China to Announce Cap-and-Trade Program to Limit Emissions', New York Times (New York, 24 September 2015) <http://www. nytimes.com/2015/09/25/world/asia/xi-jinping-china-president-obama-summit.html?_ $\mathrm{r}=0>$ accessed 2 December 2015.

33 Center for Climate and Energy Solutions, Q\&A: EPA Regulation of Greenhouse Gas Emissions from Existing Power Plants <http://www.c2es.org/federal/executive/epa/q-aregulation-greenhouse-gases-existing-power $>$ accessed 2 December 2015. 
Commission will have to take into account the fact that the EU ETS has been suffering from the over-allocation of emission allowances and a low carbon price and that it has so far produced relatively modest results, as admitted by the Commission itself. ${ }^{34}$ In order to be fair towards third countries which export carbon leakage sensitive products into the EU, the Commission will have to assess the Union's commitment to reduce its greenhouse gas emission in a self-critical manner and in the light of the above-mentioned difficulties the EU ETS has been facing. Should a country's commitment to climate change mitigation be assessed only on the basis of its policy choices, it could be argued that in the long run all countries could be considered as taking comparable action since they are parties to the recently adopted Paris Agreement and are taking some form of action in accordance with the principle of 'common but differentiated responsibilities and respective capabilities, in the light of different national circumstances'. Since one of the criteria for assessing the comparability of third-country action is the time frame within which emission reductions are taking place, the newly adopted Paris Agreement will not be relevant for the period running until 2020.

On the basis of the aforementioned criteria, and as required by Article 10(a)13 of the EU ETS Directive, the European Commission has adopted two decisions which identified the sectors and subsectors exposed to significant risk of carbon leakage. ${ }^{35}$ The first list, adopted by the Commission after a thorough stakeholder consultation process and in agreement with the Council and the European Parliament, included 164 sectors, such as the production of iron, steel, aluminium, paper, pulp, cement, lime and others, and in 2009 covered approximately $75 \%$ of all industrial emissions within the EU ETS, ${ }^{36}$ which equals approximately $40 \%$ of all emissions covered by the ETS in 2009. Such a high number of sectors which were assessed to be at significant risk of carbon leakage confirmed concerns whether the criteria for their identification had been properly framed. ${ }^{37}$

\footnotetext{
34 Commission, 'Proposal for a Directive of the European Parliament and of the Council amending Directive 2003/87/EC to enhance cost-effective emission reductions and lowcarbon investments COM (2015) 337 final, 2015/148 (COD) 5, 13.

35 The first decision was applicable to the 2013-2014 period: Commission Decision of 24 December 2009 determining, pursuant to Directive 2003/87/EC of the European Parliament and of the Council, a list of sectors and subsectors which are deemed to be exposed to significant risk of carbon leakage [2010] OJ L1/10. The list of sectors exposed to the significant risk of carbon leakage has so far been amended several times, by Commission Decisions 11/11/2011 - 2011/745/EU, 17/08/2012 - C (2012) 5715 and 18/12/2013 - C (2013) 9186. The second decision applies to the 2015-2019 period - Commission Decision of 27 October 2014 determining, pursuant to Directive 2003/87/EC of the European Parliament and of the Council, a list of sectors and subsectors which are deemed to be exposed to a significant risk of carbon leakage, for the period 2015 to 2019 (2014/746/EU).

36 According to the data provided by an official of DG Climate Action. See Bergman (n 26).

37 For a summary of methodological flaws of the carbon leakage list, see Dröge and Cooper (n 24) 25-28.
} 
According to an analysis made by Clò, ${ }^{38}$ out of 140 sectors which were in 2009 considered to be exposed to significant risk of carbon leakage based on the quantitative criteria, 134 have entered the list mainly because of their high trade exposure, regardless of their carbon intensity. ${ }^{39}$ Eighty-three of those sectors were liable for a cost increase lower than $1 \%$. Out of the listed 140 sectors, only 6 satisfied the cumulative criteria from Article 10(a)15, which ensures that a sector faces a higher cost increase, meaning that it is carbon intensive, and is significantly trade exposed. ${ }^{40}$ Consequently, that criterion is the only one suitable for identifying the sectors at risk. ${ }^{41}$ Clò therefore concludes that the criteria for determining the sectors at risk are not sufficiently grounded and have been set as a political compromise. ${ }^{42}$ This conclusion is supported by the fact that the Article 10(a) 16 criterion which the majority of sectors met and thereby had entered the list, requires only trade exposure of $30 \%$ or higher, regardless of the impact of the EU ETS on that sector, or a cost increase of $30 \%$ or higher, regardless of whether or not that cost can be passed on to consumers and whether or not the sector is exposed to international trade. ${ }^{43}$ Even though Article 10(a) 14 of the EU ETS Directive states that in order to determine the sectors which are exposed to a significant risk of carbon leakage, the Commission shall assess the ability of sectors to 'pass on the direct cost of the required allowance and the indirect costs from higher electricity prices resulting from the implementation of this Directive into product prices without significant loss of market share to less carbon efficient installations outside the Community', the determination of a cost pass-through rate bares no relation to the first alternative criterion of Article 10(a)16. The ability of a market operator to pass through its direct and indirect costs to consumers depends on the structure of the market and the level of competition in it, the elasticity of demand and exposure to international trade. ${ }^{44}$

The extent to which the list includes a too broad number of sectors can perhaps best be illustrated by listing some of the sectors which are

\footnotetext{
38 Stefano Clò, 'Grandfathering, Auctioning and Carbon Leakage: Assessing the Inconsistencies of the New ETS Directive' (2010) 38 Energy Policy 2420, 2426.

39 The same conclusion about the inadequacy of the criterion was reached in Sean Healy and Katja Schumacher, 'Support to the Commission for the Determination of the List of Sectors and Subsectors Deemed to Be Exposed to a Significant Risk of Carbon Leakage for the Years 2015-2019 (EU Emission Trading System)' (2013) Literature Review, ÖkoInstitut $\mathrm{eV}$ and Ecofys 10 <http://ec.europa.eu/clima/policies/ets/cap/leakage/docs/ carbon_leakage_list_en.pdf > accessed 13 November 2015.

40 Clò (n 38) 2426. Slightly different data in Dröge and Cooper (n 24) 26.

41 Clò (n 38) 2428.

42 ibid. The same view has been shared in Stéphanie Monjon and Philippe Quirion, "How to Design a Border Adjustment for the European Union Emissions Trading System?' (2010) 38 Energy Policy 5199, 5203.

43 Clò (n 38) 2427.

44 Healy and Schumacher (n 39) 11.
} 
considered to be exposed to a significant risk of carbon leakage: manufacture of brooms and brushes (cost increase $<5 \%$, trade intensity $43.3 \%$ ), manufacture of carpets and rugs (cost increase $0.8 \%$, trade intensity $31.2 \%$ ) and building and repairing of pleasure and sporting boats (cost increase $0.3 \%$, trade intensity $62 \%) .{ }^{45}$ Further concerns are raised by the fact that the assessments about the future cost increases for the 20132014 list, which was composed in 2009, were based on the assumption that the EU ETS allowance price would remain at around $€ 30,{ }^{46}$ a level which it only briefly reached in 2006 and which it only approached at the end on 2008. Given that the actual allowance price in 2013 and 2014 varied between $€ 3$ and $€ 6$, the number of sectors which are in practice exposed to a significant risk of carbon leakage is much lower. However, for the purposes of determining the new list of sectors and subsectors at risk for the 2015-2019 period, the Commission proposed to use the same price assumption of $€ 30 .{ }^{47}$ In its explanation, the Commission acknowledged the discrepancy between the projected price which was used as the calculation basis for the first list in 2009 and actual prices. It justified its proposal to use the same $€ 30$ price assumption by the fact that a $40 \%$ emission reduction target had been proposed for 2030 and by its proposal for a market stability reserve, because the Commission expected that the market stability reserve, once adopted, would raise the allowance prices in the future. ${ }^{48}$ The Commission's proposal of the new carbon leakage list was accepted by the European Parliament Environment Committee in September 2014 and, after being approved by the Council, finally adopted by the Commission in October 2014. ${ }^{49}$ Notwithstanding possible market developments, it seems rather unlikely that the prices of EU ETS allowances will increase up to $€ 30$ per allowance, at least not during the first few years of the relevant period. The main reason why such an increase seems highly improbable is the fact that in summer 2014 the EU ETS market suffered from 213 million surplus allowances. The backloading decision, adopted by the Commission, might remedy the

\footnotetext{
45 Overview of NACE-4 level carbon leakage assessments ('present assessment' as sent to the Climate Change Committee on 5 May 2014) <http://ec.europa.eu/clima/policies/ets/ cap/leakage/docs/carbon_leakage_comparison_en.pdf > accessed 13 November 2015.

46 Draft Commission Staff Working Document (n 25) 5.

47 Draft of the Commission Decision determining, pursuant to Directive 2003/87/EC of the European Parliament and of the Council, a list of sectors and subsectors which are deemed to be exposed to a significant risk of carbon leakage, for the period 2015 to 2019, 4 <http:/ / ec.europa.eu/clima/policies / ets/cap/leakage/docs/20140502_decision_en.pdf> accessed 13 November 2015.

48 ibid.

49 EurActiv, 'EU Agrees to $€ 5$ bn Carbon Permit Giveaway (25 September 2014) <http:// www.euractiv.com/sections/energy/eu-agrees-eu5bn-carbon-permit-giveaway-308702> accessed 13 November 2015; European Commission, DG Climate Action, 'Carbon Leakage' <http://ec.europa.eu/clima/policies/ets/cap/leakage/index_en.htm> accessed 1 December 2015 .
} 
situation partially, but its impact is dubious because it only postpones the auctioning of allowances and does not remove them from the market. The reasons for the price increase quoted by the Commission came in May 2014, when the draft decision on the sectors at risk of carbon leakage was published, still only proposals, and the Commission should not have been as confident in relying on the ability of those proposals to achieve such a strong increase in the carbon price in such a short period. The market stability reserve is unlikely to influence the allowance prices in the 2015-2019 period for which the list is drafted, because the market stability reserve will only become operational on 1 January $2019 .{ }^{50}$ It is therefore disappointing that the Commission did not decide to strengthen the EU ETS Directive's loose criteria for determining the sectors at risk of significant carbon leakage, but instead chose a very improbable, but very industry-favourable allowance price scenario for the basis of its calculations. By doing so, the Commission contributed to the higher percentage of freely allocated allowances between 2015 and 2019, which runs contrary to the EU ETS's tendency to increase the proportion of auctioning of allowances.

\subsection{Current carbon leakage mitigation measures under the EU ETS Directive}

Due to the described high share of sectors exposed to carbon leakage in the overall sectors subject to the EU ETS, the choice of mitigating measures is crucial for the efficient functioning of the scheme and the achievement of the goals of greenhouse gas emission reduction. The EU ETS Directive equips the scheme with three methods for the mitigation of carbon leakage from the stationary sectors which are covered by it. The only mitigation measure which has so far been put in place in all Member States at the Union level is the free allocation of emission allowances to the sectors exposed to significant risk of carbon leakage. The second measure envisaged by the Directive is financial support to sectors at risk, which is decided upon and provided by each Member State individually. The third option for addressing carbon leakage envisaged by the Directive is the possibility of the introduction of border carbon adjustments.

\subsubsection{Free allocation of allowances}

The main mitigation instrument that the EU legislator opted for in order to remedy the competitive position of sectors and subsectors which are exposed to significant risk of carbon leakage is the free allocation of

50 Decision (EU) 2015/1814 of the European Parliament and of the Council of 6 October 2015 concerning the establishment and operation of a market stability reserve for the Union greenhouse gas emission trading scheme and amending Directive 2003/87/EC, Article $1(1)$. 
allowances, the number of which is determined on the basis of Unionwide ex-ante benchmarks. ${ }^{51}$ The main difference between the free allocation of allowances to sectors which are at significant risk of carbon leakage, when compared to other sectors which also receive allowances for free during the third trading period, is the fact that sectors at significant risk of carbon leakage are eligible to receive $100 \%$ of their allowances for free, while the quantity of free allowances to other sectors is declining annually, starting with $80 \%$ of free allowances in 2013, and ending with $30 \%$ in 2020 , while no free allocation for those sectors will be possible in 2027. ${ }^{52}$ However, even though the sectors at significant risk of carbon leakage are in theory eligible to receive all of their allowances for free, the exact number of free allowances they will actually receive is dependent on the extent to which a specific greenhouse gas emitting installation satisfies the relevant sector's benchmark. ${ }^{53}$

\section{Benchmarking}

Ellerman and Buchner define benchmarking as: 'A principle of allocation whereby some index of historical activity or capacity is multiplied by a usually uniform emission-rate standard to determine allocations to individual installations'. ${ }^{54}$ Benchmarking aims to ensure that two market participants which are similar regarding production factors, except emissions, are treated alike and that the undertaking with higher emissions does not receive more allowances than the one with lower emissions. ${ }^{55}$

The EU ETS benchmarks are product-based and are set on the basis of "the average performance of $10 \%$ of most efficient installations in a sector or subsector in the Community in the years 2007-2008'. ${ }^{56}$ By setting the benchmark at the top $10 \%$ of the most efficient installations, the Union legislator rewarded those installations which took early action for reducing their greenhouse gas emissions. ${ }^{57}$ Benchmarks are set individually for products from each sector and subsector which has been listed as exposed to the significant risk of carbon leakage. Furthermore, benchmarks are set at the Union level, which ensures that the same standards for the free allocation of allowances apply in all Member States, which minimises the chances of distorted competition and strengthens the internal market. The EU ETS Directive provides only for ex-ante

51 Article 10(a) 12 of the consolidated text of the EU ETS Directive.

52 Article 10(a) 11 of the consolidated text of the EU ETS Directive.

53 Article 10(a) 12 of the consolidated text of the EU ETS Directive.

54 A Denny Ellerman and Barbara K Buchner, 'The European Union Emissions Trading Scheme: Origins, Allocation and Early Results' (2007) 1(1) Review of Environmental Economics and Policy 66, 76.

55 ibid.

56 Article 10(a)2 of the consolidated text of the EU ETS Directive.

57 Ellerman, Convery and De Perthuis (n 22) 64. 
benchmarks, ${ }^{58}$ meaning that the benchmarks on the basis of which free allowances are allocated are set in advance and take into account the historic emissions of an installation, not its future ones. The installations are therefore allocated a pre-defined quantity of free allowances, regardless of how much their future emissions will amount to during the relevant commitment period. ${ }^{59}$

However, the benchmark-setting process itself has been long and burdensome. Due to time constraints, data insufficiencies, differences between installations within the sectors and non-existing previous standards which could serve as benchmarks, timely definitions of benchmarks were mostly not available during the first and second commitment periods, and emission allowances were therefore distributed on the basis of the installations' historic emissions. ${ }^{60}$ The initial difficulties regarding benchmark setting were overcome by 2011 when the Commission published the 'Benchmarking Decision' which contains the list of applicable product benchmarks. ${ }^{61}$ Concerns have been raised that the benchmarksetting process resulted in some inefficiencies and needs further improvements. ${ }^{62}$ The benchmark of the top $10 \%$ efficient installations operating in the Union has several advantages and disadvantages. Its main advantage is that it can be determined relatively easily, while its biggest flaw is that it does not necessarily ensure sufficient progress towards carbon efficient technologies in cases where the top $10 \%$ of installations in the sector are still using carbon intense technologies. This problem can more successfully be addressed by the best available technology (BAT) benchmark, but its determination is often very complex. Fast technological developments would require frequent changes of the BAT benchmark, which does not provide a sufficient level of certainty for investors. Furthermore, the best available technology might often be too expensive for most installations, which leads to its practical application as a best available technology not entailing excessive cost (BATNEEC) benchmark. ${ }^{63}$

\section{Free allocation $\mathrm{v}$ auctioning}

The main idea behind the free allocation of allowances to sectors at significant risk of carbon leakage is to remedy their competitive posi-

\footnotetext{
58 Article 10(a) 1 of the consolidated text of the EU ETS Directive.

59 The same in Spassov (n 16) 321.

60 Ellerman and Buchner (n 54) 77. In the described scenario in which reliable benchmarks could not have been set, historic emissions are considered to be a more acceptable standard. Ellerman, Convery and De Perthuis (n 22) 65.

61 Commission Decision of 27 April 2011 determining transitional Union-wide rules for harmonised free allocation of emission allowances pursuant to Article 10a of Directive 2003/87/EC of the European Parliament and of the Council [2011] OJ L130/1.

62 Dirk Böhler, 'The EU Emissions Trading Scheme: Fixing a Broken Promise' (2013) 15 Environmental Law Review 95, 99-100; Spassov (n 16) 321.

63 Ellerman, Convery and De Perthuis (n 22) 66.
} 
tion, which might be threatened by international production not subject to comparable internalisation of carbon costs, and thereby to prevent carbon leakage. ${ }^{64}$ It must be emphasised that the fact that sectors at significant risk of carbon leakage are eligible to receive $100 \%$ of all their allowances for free does not amount to the exclusion of those sectors from the scope of the EU ETS. Those sectors are still responsible for surrendering the quantity of allowances corresponding to their greenhouse gas emissions at the end of the commitment period. Furthermore, the sectors at significant risk of carbon leakage are not necessarily allocated all of their allowances for free - only those installations which satisfy the relevant product benchmarks are. Even then, should those installations increase their emissions above the estimated level, they will have to purchase additional allowances to cover those additional emissions. Nevertheless, even though sectors which are at significant risk of carbon leakage are not excluded from the EU ETS, they are given an advantage in comparison to other sectors covered by the EU ETS, at the expense of the final consumers of their products.

Free allocation of emission allowances, often referred to as grandfathering, ${ }^{65}$ has attracted most of the EU ETS related critiques. One of the main concerns regarding free allocation which served as the predominant method of distribution of allowances during the first two trading periods, and still constitutes the dominant method at the beginning of the third trading period, is that it enabled the sectors covered by the EU ETS to gain windfall profits. ${ }^{66}$ Windfall profits occurred at a higher scale during the first two trading periods because some of the sectors, such as the power sector, to which free allowances were allocated, passed their carbon cost to the consumers and thereby earned profits, since they did not pay for the allowances in the first place. From the economic perspective, this can be explained by the fact that the market value of a free allowance represents an opportunity cost to the market operator it was allocated to. That market operator has the choice either to reduce its emissions and sell the allowance, or to continue with the businessas-usual production, and use the allowance to cover its emissions. In

\footnotetext{
64 Similarly Dröge and Cooper (n 24) 33; Peretz (n 13) 87.

65 Ellerman, Convery and De Perthuis (n 22) 61; Robert C Schmidt and Jobst Heitzig, 'Carbon Leakage: Grandfathering As an Inventive Device to Avert Firm Relocation' (2014) 67 Journal of Environmental Economics and Management 209, 210. The authors define grandfathering as: 'free allocation of permits in proportion to some historical variable (eg, emissions) of the firm'.

66 A Denny Ellerman, Claudio Marcantonini and Aleksandar Zaklan, 'The EU ETS: Eight Years and Counting' EUI Working Papers RSCAS 2014/04, 3 <http://ssrn.com/abstract $=2383870>$ accessed 13 November 2015; Ellerman and Buchner (n 54) 73; Peretz (n 13) 89; Sandbag, 'Carbon Fat Cats 2011: The Companies Profiting from the EU Emissions Trading Scheme' (June 2011) <http://www.sandbag.org.uk/site_media/pdfs/reports/ Sandbag_2011-06_fatcats.pdf> accessed 13 November 2015.
} 
the latter case, should the lost profit which could have been made if the allowance were sold, in the amount of the difference between the market price of the allowance and the cost of emission reduction which the market operator undertook, not be retrieved from the consumers, that would represent lost profits and would constitute economically inefficient behaviour. By passing the cost of the potential profit to the consumers, the market operator is taking the price of allowance into account while making business decisions. Since carbon intensive products thereby become more expensive, consumers are likely to gradually shift towards products of lower carbon intensity. ${ }^{67}$ This analysis shows that the free allocation of allowances is capable of producing the same emission reduction effects as auctioning. ${ }^{68}$ The main difference between the two, however, lies in who pays for the emission reductions to whom. ${ }^{69}$ When emission allowances are auctioned, the installation which buys the allowance makes payment for the allowance to the entity issuing it, mainly the government. If it is able to pass that cost to the consumer it will be able to recover that cost, which will not be considered as windfall profits. On the other hand, in the case of the free allocation of allowances, if the market operator passes the cost of the allowance to the consumers, it is the market operator who will keep the profits, not the government. Since the market operator did not pay for the allowance, those profits will be windfall profits. If the market operator is not able to pass the cost to the consumers, no profits will be earned. This shows that the free allocation of allowances which leads to windfall profits is not in line with the polluter pays principle. ${ }^{70}$ The 2009 amendments of the EU ETS Directive addressed concerns about windfall profits by expressly excluding the power sector from the sectors eligible for the free allocation of allowances. ${ }^{71}$ The EU power sector, which is responsible for approximately $50 \%$ of EU ETS emissions, is the sector most capable of passing the carbon price to consumers, since it does not suffer from international competition due to the geographical isolation of the EU from potential importers of electricity. ${ }^{72}$ Given the fact that the power

\footnotetext{
67 Clò (n 38) 2422. For a completely opposite view, see Peretz (n 13) 89; K Holzer, Carbonrelated Border Adjustment and WTO Law (Edward Elgar Publishing 2014) 48.

68 Ellerman, Convery and De Perthuis (n 22) 86.

69 Clò (n 38) 2422.

70 Woerdman, Arcuri and Clò conclude that grandfathering is consistent with the so called 'weak' and 'strong forms of the polluter pays principle, but that it might be problematic from the "extended" form of the polluter pays principle, which encompasses the equity perspective, because polluting firms do not have to purchase the emission rights while their shareholders become richer'. Edwin Woerdman, Alessandra Arcuri and Stefano Clò, 'Emissions Trading and the Polluter-Pays Principle: Do Polluters Pay under Grandfathering?'(2008) 4(2) Review of Law and Economics 565, 586; Stefan Weishaar, Towards Auctioning: The Transformation of the European Greenhouse Gas Emissions Trading System: Present and Future Challenges to Competition Law (Kluwer Law International 2009) 103.

71 Article 10(a) 1 of the consolidated text of the EU ETS Directive.

72 Ellerman, Marcantonini and Zaklan (n 66) 3.
} 
sector is in principle not eligible for free allowances, it can be concluded that the risk of windfall profits is significantly lower in the third EU ETS trading period. However, due to the very broad definition of the sectors exposed to a significant risk of carbon leakage, the possibility of windfall profits cannot be excluded.

Due to the above-mentioned conclusion that the carbon price is internalised in the business decisions of market operators to which allowances were allocated for free, and that free allocation is therefore equally efficient as auctioning, it cannot be claimed that the free allocation of allowances increases the pressure for higher levels of carbon abatement in the remaining EU ETS sectors. Furthermore, some studies have shown that grandfathering can be used as an effective tool to prevent firm reallocations both in the short and long term. ${ }^{73}$ In the short term, free allowances annul the carbon cost and therefore eliminate the incentive for firm reallocation. In the long run, a carefully designed and gradually phased out grandfathering scheme can provide an incentive for investments in emission reductions, which can, due to a lock-in effect of invested capital, render the reallocation inefficient. ${ }^{74}$

On the other hand, it cannot be denied that the free allocation of allowances deprives the state of potential budgetary revenue which could be used for climate change mitigation measures. At the same time, the fact that the free allocation of allowances does not represent any cost to market operators makes it more politically acceptable. As stated by Tietenberg, 'free distribution of permits (as opposed to auctioning them off) seems to be a key ingredient in the successful implementation of emission trading programs'.$^{75}$ Apart from alleviating the introduction of a cap and trade system, the free allocation of allowances can also reduce the resistance of the covered sectors to more stringent emission reduction goals. ${ }^{76}$

\subsubsection{Financial measures}

The second instrument which can be used by Member States for the prevention of carbon leakage is envisaged in Article 10(a)6 of the EU ETS Directive, which prescribes that 'Member States may also adopt financial measures in favour of sectors or subsectors determined to be exposed to a significant risk of carbon leakage due to costs relating to greenhouse

73 Schmidt and Heitzig (n 65) 219.

74 ibid.

75 Bård Harstad and Gunnar S Eskeland, 'Trading for the Future: Signalling in Permit Markets' (2010) 94 Journal of Public Economics 749, 749, citing T Tietenberg, Emissions Trading: Principles and Practice ( $2^{\text {nd }}$ edn, RFF Press 2006).

76 Schmidt (n 65) 209, citing T Sterner and LH Isaksson, 'Refunded Emission Payments: A Hybrid Instrument with Some Attractive Properties' (2006) 57 Ecological Economics 93. 
gas emissions passed on in electricity prices, in order to compensate for those costs'.

The main reason why the EU ETS Directive contains the abovementioned provision, which enables financial assistance to sectors which are at significant risk of carbon leakage, is to remedy certain distortions caused by the fact that the power sector is able to pass the full cost of emission allowances to its consumers. This consequently leaves energyintensive industries vulnerable to higher electricity prices. Unlike the electricity generating sector and due to stronger competition on their markets, energy intensive industries often cannot pass the increase of their production costs to the consumers. The increase of their indirect costs cannot be remedied by the free allocation of allowances, since free allowances cover only direct carbon costs, ie only direct emissions from the installation they were allocated to. However, as stated in Article 10(a)6, not all sectors which have been put on the significant carbon leakage risk list are eligible to receive financial support, but only those which are energy intensive, and which are put on the list due to the increase in their indirect costs. An example of such a sector is the production of aluminium, where 'electricity represents $30 \%$ to $40 \%$ of the production cost'. ${ }^{7}$

Even though direct financial support to the above-mentioned sectors is capable of alleviating their competitive position, this carbon leakage mitigation measure at the same time suffers from too broad an application. It is therefore liable to represent an excessive financial burden on the Member States which decide to apply it and to cause competitive distortions, because some Member States might have sufficient resources to grant the aid, while others might not. ${ }^{78}$ Pursuant to Article 10(a)6 of the EU ETS Directive, Member States may 'adopt financial measures in favour of sectors or subsectors determined to be exposed to a significant risk of carbon leakage due to costs relating to greenhouse gas emissions passed on in electricity prices'. Article 10(a)6 therefore refers to Article 10 (a) paragraph 16 (a) for the determination of the sectors which are at significant risk of carbon leakage, which sets the criteria for the free allocation of allowances. As analysed above in section 2.1 of this paper. Article 10(a) paragraph 16(a) only takes into account whether a $30 \%$ or higher increase of production costs occurs in a given sector (which, in order for Article 10(a) 6 to be applicable, has to derive from increased electricity prices), regardless of the fact of whether that sector is capable of passing the increased cost of production to the consumers. When other

\footnotetext{
77 Peretz (n 13) 66, citing China Aluminium Network, 'EAA Warns Emissions Trading Could Hurt European Aluminium Sector' <http://www.alu.com.cn/enNews/NewsInfo_2735. html> accessed 13 November 2015.

78 Point 8 of the Communication from the Commission - Guidelines on certain State aid measures in the context of the greenhouse gas emission allowance trading scheme post2012 (2012/C 158/04).
} 
concerns about the methodology of determining the list of sectors at significant risk of carbon leakage are taken into account, special attention should be paid to a very narrow application of this mitigation measure. Should financial assistance be given to the installations which are capable of passing their increased production costs to consumers, this could lead to windfall profits and to a violation of state aid rules.

This issue was addressed by the Commission in its 2012 Guidelines on state aid in the context of the ETS, where a special definition of carbon leakage was adopted for the purpose of the application of the Guidelines. According to the Guidelines, carbon leakage: 'describes the prospect of an increase in global greenhouse gas emissions when companies shift production outside the Union because they cannot pass on the cost increases induced by the EU ETS to their customers without significant loss of market share'. ${ }^{79}$ The Guidelines therefore narrow the scope of application of Article 10(a)6 of the EU ETS Directive in a way that they exclude the companies which can pass the carbon cost to the consumers. Furthermore, the Guidelines set the formula for the calculation of the maximum amount of aid that can be awarded to a single installation. ${ }^{80}$ The maximum intensity of aid is also set, starting at $85 \%$ of eligible indirect costs in 2013, and ending with $75 \%$ coverage in 2020 , which should ensure that the installations which the aid is awarded to are not aid dependant and do not lose incentives to switch to power sources of lower carbon intensity. ${ }^{81}$ Annex II to the Guidelines contains the list of all sectors and subsectors deemed ex-ante to be exposed to a significant risk of carbon leakage due to indirect emission costs. According to the Guidelines, only 15 sectors which are listed in Annex II, such as aluminium production and the manufacture of paper and paperboard, are eligible to receive financial aid under Article 10(a)6 of the EU ETS Directive. The Guidelines therefore significantly narrowed the list of potential sectors which could benefit from financial assistance when compared to the potential recipients under the EU ETS Directive. Even though the Guidelines are not legally binding on Member States, they should be taken into account because they provide indication of whether the Commission is likely to consider the aid lawful. However, a problem remains that the Directive does not expressly authorise the Commission to narrow the scope of application of Article 10(a)6 by adopting restrictive guidelines, but only states that the financial measures must be 'in accordance with state aid rules applicable and to be adopted in this area'. ${ }^{82}$ According to the case law of the Court of Justice of the European Union, an instrument of soft

9 ibid, point 7.

80 ibid, point 27.

31 ibid, points 12 and 26.

82 Article 10(a) 6 of the consolidated text of the EU ETS Directive. 
law cannot modify the mandatory rules contained in hard law. ${ }^{83}$ This conclusion is a logical consequence of the legislative procedure in the Union. Since consent of the Parliament and the Council is necessary for a legislative act to be enacted, it would be contrary to the democratic foundations of the legislative procedure if the Commission could unilaterally modify it. The status of the Guidelines therefore remains questionable.

Current data show that some Member States have decided to make use of Article 10(a) 6 of the EU ETS Directive and grant financial assistance due to carbon leakage. According to a study made by Marcu and others, 'at least five member states and Norway provide this compensation (UK, Germany, Netherlands, Spain and Belgium (Flanders region))'. ${ }^{84}$

\subsubsection{Border carbon adjustments}

The third and final tool for addressing carbon leakage envisaged by the EU ETS Directive is the possibility of introducing border carbon adjustments. Article 10(b) paragraph 1(b) of the Directive authorises the Commission to propose the inclusion in the Community scheme of importers of products which are produced by the sectors or subsectors determined in accordance with Article 10a' (sectors exposed to significant risk of carbon leakage). The Commission has so far not exercised this authority to propose the introduction of border carbon adjustments into the EU ETS. They therefore so far only remain a future option. The most recent consideration of the introduction of a border carbon adjustment was made in 2014, when the European Parliament called the Commission to 'examine the feasibility of a border carbon adjustment' for the steel sector. ${ }^{85}$ However, the introduction of border carbon adjustments was not proposed by the Commission in its EU ETS amendment proposal of 2015.

\section{Carbon leakage mitigation under the Commission's EU ETS amend- ment proposal of 2015}

In July 2015, the Commission issued its proposal for the amendment of the EU ETS Directive. Among some of the biggest changes contained in the proposal is a thorough reform of Article 10(b) entitled 'Measures to support certain energy-intensive industries in the event of carbon leakage', which, should the Commission's proposal be adopted by the Parliament and the Council, will be worded as follows:

\footnotetext{
83 Case C-266/90 Franc Soba KG v Hauptzollamt Augsburg ECLI:EU:C:1992:36 para 19. The judgment in Soba contained a modification of the provisions of a Regulation via an interpretative note.

84 Marcu and others (n 10) 26.

85 European Parliament resolution of 17 December 2014 on the steel sector in the EU: protecting workers and industries (2014/2976(RSP)) <http://www.europarl.europa.eu/sides / getDoc.do?pubRef=-\%2f\%2fEP $\% 2 f \% 2 f T E X T \% 2 b T A \% 2 b P 8-T A-2014-0104 \% 2 b 0 \% 2 b D O C \% 2$ bXML\%2bV0\%2f\%2fEN\&language=EN> accessed 2 December 2015.
} 
1. Sectors and sub-sectors where the product exceeds 0.2 from multiplying their intensity of trade with third countries, defined as the ratio between the total value of exports to third countries plus the value of imports from third countries and the total market size for the European Economic Area (annual turnover plus total imports from third countries), by their emission intensity, measured in $\mathrm{kgCO}_{2}$ divided by their gross value added (in $€$ ), shall be deemed to be at risk of carbon leakage. Such sectors and sub-sectors shall be allocated allowances free of charge for the period up to 2030 at $100 \%$ of the quantity determined in accordance with the measures adopted pursuant to Article 10a.

2. Sectors and sub-sectors where the product from multiplying their intensity of trade with third countries by their emission intensity is above 0.18 may be included in the group referred to in paragraph 1 , on the basis of a qualitative assessment using the following criteria:

a) the extent to which it is possible for individual installations in the sector or sub-sectors concerned to reduce emission levels or electricity consumption;

(b) current and projected market characteristics;

(c) profit margins as a potential indicator of long-run investment or relocation decisions.

3. Other sectors and sub-sectors are considered to be able to pass on more of the cost of allowances in product prices, and shall be allocated allowances free of charge for the period up to 2030 at $30 \%$ of the quantity determined in accordance with the measures adopted pursuant to Article 10a. ... ${ }^{86}$

The Commission's EU ETS amendment proposal thereby completely changes the method of determining the list of the sectors which are exposed to significant risk of carbon leakage. However, despite the fact that, according to the Commission's estimates, the number of sectors which will be considered as exposed to significant risk of carbon leakage will be narrowed down from the current 177 to only 50,87 the list will still encompass $90 \%$ of all industrial emissions (compared to the current 97\%). ${ }^{88}$ Even though the proposed reform of the identification of sectors which are exposed to a significant risk of carbon leakage ensures that the car-

\footnotetext{
86 Commission, 'Proposal for a Directive of the European Parliament and of the Council amending Directive 2003/87/EC to enhance cost-effective emission reductions and lowcarbon investments' COM (2015) 337 final, 2015/148 (COD) 20.

87 European Parliament, Briefing EU Legislation in Progress, 18 September 2015, Post-2020 reform of the EU Emissions Trading System 5 <http://www.europarl.europa.eu/RegData/ etudes/BRIE/2015/568334/EPRS_BRI(2015)568334_EN.pdf> accessed 3 November 2015). 88 ibid, 5 .
} 
bon intensity of all sectors is always taken into account, and thereby addresses one of the main drawbacks of the currently applicable methodology, it can be seen that it makes little difference in practice due to the fact that the threshold values have been set too low. Furthermore, according to the above-mentioned Commission's proposal, sectors exposed to significant risk of carbon leakage are scheduled to continue receiving free allowances, albeit on an updated benchmarking system. More regular updates of the allowance allocation benchmarks have been proposed with the aim of avoiding windfall profits and adjustment to the technological progress which has taken place since 2007 and 2008, when the original benchmark data were collected. ${ }^{89}$ Nevertheless, despite the improvements in the benchmarking system, it can generally be concluded that the Commission has not made use of the opportunity to effectively address the main weaknesses of the existing carbon leakage regulation in the European Union.

\section{Conclusion}

The performed analysis of European Union's carbon leakage mitigation measures shows that the system leaves ample room for improvement. The current legislative solution contained in the EU ETS Directive allows for a sector to be categorised as exposed to a significant risk of carbon leakage solely on the basis of its trade exposure and regardless of the carbon intensity of that sector. Moreover, the majority of sectors have found their way to the current carbon leakage list precisely due to the trade exposure criterion. The described legislative solution leads to the overprotection of the sectors which are considered to be exposed to a significant risk of carbon leakage. ${ }^{90}$ This issue has been addressed in the Commission's EU ETS amendment proposal of 2015, although the proposed changes are capable of producing a very limited effect in practice. Nevertheless, it should be emphasised that this amendment proposal might become further strengthened in the legislative process, as has recently occurred with the market stability reserve ${ }^{91}$ and the extension of the EU ETS to the aviation sector. ${ }^{92}$

\footnotetext{
89 Commission (n 86) 18.

90 The same conclusion has been reached by Ralf Martin and others, 'On the Empirical Content of Carbon Leakage Criteria in the EU Emissions Trading Scheme' (2014) 105 Ecological Economics 78, 84-85.

91 Decision (EU) 2015/1814 of the European Parliament and of the Council of 6 October 2015 concerning the establishment and operation of a market stability reserve for the Union greenhouse gas emission trading scheme and amending Directive 2003/87/EC. The Commission first proposed that the market stability reserve become operational in 2021 , but, due to the amendments proposed by the Parliament, a more stringent date was finally introduced and the deadline was moved to 2019. For a comparison of the Commission's and the Parliament's stance on the issue, see the European Parliament report of 2 March 2015 <http: / / www.europarl.europa.eu / sides / getDoc.do?type=REPORT\&reference=A8-20150029\&format=XML\&language=EN $>$ accessed 2 December 2015.

92 EurActiv, 'Kallas: Global Aviation Emissions Talks "A Nightmare"' <http://www.eura-
} 
Additional strengthening of the European Union's carbon leakage rules is necessary because the current overprotection of sectors which are considered to be exposed to a significant risk of carbon leakage ultimately leads to the loss of potential revenue which could be used for financing climate change mitigation and adaptation. Climate financing, along with the principle of common but differentiated responsibilities and respective capabilities, in the light of different national circumstances, have represented the most difficult items on the Paris agenda. Should the European Union take its financial commitments seriously and meaningfully contribute to delivering the USD 100 billion per year pledge which was made in December 2015, ${ }^{93}$ it should strive to mobilise all available financial resources for climate financing of developing country mitigation and adaptation. This conclusion is further emphasised by recent studies which show that the European Union's current intended nationally determined contribution, which consists of a $40 \%$ reduction of greenhouse gas emissions by 2030 from 1990 levels, 'falls short of leadership and of a fair share' for which the European Union is responsible. ${ }^{94}$

Finally, the fact that current carbon leakage rules in the European Union lead to the overprotection of sectors which are considered to be exposed to a significant risk of carbon leakage has also recently been confirmed by several ex-post studies, which found no evidence of a carbon leakage risk. ${ }^{95}$ This factor should be taken into account by the European Union legislator during the upcoming revision of the EU ETS. Even though carbon leakage rules are necessary in the current global carbon pricing system, they should be better tailored to preserve the environmental and economic integrity of the Union's climate change legislation in a way which does not unnecessarily burden the system and lead to the overprotection of certain industries. Such an outcome is crucial for the European Union's climate change action in the global arena, since its legitimacy depends on the European Union's ability to deliver on its promises at both the domestic and international level.

ctiv.com/transport/kallas-calls-global-talks-aviati-news-533967> accessed 2 December 2015.

93 Conference of the Parties to the United Nations Framework Convention on Climate Change, Adoption of the Paris Agreement, 12 December 2015, Decision of CP 21, point 54 <http://unfccc.int/resource/docs/2015/cop21/eng/109r01.pdf > accessed 12 December 2015 .

94 University of Melbourne, Melbourne Sustainable Society Institute, 'What Does Climate Leadership and a "Fair Share" Look Like?' 7 <http://sustainable.unimelb.edu.au/sites/default/files/docs/MSSI-Briefing-Paper2_Talberg2015_1.pdf > accessed 12 December 2015.

95 European Commission, Environment Agency Austria, Umweltbundesamt, 'Evaluation of the EU ETS Directive' November 2015,134 < http://ec.europa.eu/clima/policies/ets/revision/docs/review_of_eu_ets_en.pdf> accessed 12 December 2015. Similarly in Ralf Martin, Mirabelle Muuls and Urlich J Wagner, 'The Impact of the European Union Emissions Trading Scheme on Regulated Firms: What Is the Evidence after Ten Years?' (2015) Review of Environmental Economic and Policy 1, 9. 